\title{
Decreased number of mast cells infiltrating into needle biopsy specimens leads to a better prognosis of prostate cancer
}

\author{
N Nonomura*,', H Takayama', K Nishimura', D Oka', Y Nakai', M Shiba', A Tsujimura', M Nakayama', \\ K Aozasa ${ }^{2}$ and A Okuyama'
}

'Department of Urology, Osaka University Graduate School of Medicine, Osaka, Japan; ${ }^{2}$ Department of Pathology, Osaka University Graduate School of Medicine, Osaka, Japan

Mast cell infiltration is often observed around human tumours. Inflammatory cells such as macrophages, neutrophils and mast cells infiltrating around tumours are known to contribute to tumour growth; however, the clinical significance of mast cell invasion in prostate cancer (PCa) has not been investigated. Mast cell infiltration was evaluated in 104 patients (age range, 45-88 years; median, 72 years), who underwent needle biopsy of the prostate and were confirmed to have PCa. Needle biopsy specimens of prostate were sliced into 5 - $\mu$ m-thick sections and immunostained for mast cells with monoclonal antibody against mast cell-specific tryptase. Mast cells were counted systematically under a microscope ( $\times 400$ magnification), and the relations between mast cell numbers and clinicopathologic findings were evaluated. The mast cell count was evaluated for prognostic value by multivariate analysis. Mast cells were immunostained around the cancer foci. The median number of mast cells in each case was 16. The mast cell count was higher around cancer foci in patients with higher Gleason scores than in those with low Gleason scores. The mast cell number correlated well with clinical stage $(P<0.00 \mathrm{I})$. Prostate-specific antigen-free survival of patients with higher mast cell counts was better than that in patients with lower mast cell counts $(P<0.00 \mathrm{I})$. Multivariate analysis revealed that mast cell count was a significant prognostic factor $(P<0.005)$. The number of mast cells infiltrating around cancer foci in prostate biopsy specimens can be a significant prognostic factor of PCa.

British Journal of Cancer (2007) 97, 952-956. doi:I0.I038/sj.bjc.6603962 www.bjcancer.com

Published online II September 2007

(C) 2007 Cancer Research UK

Keywords: biopsy; immunostaining; mast cells; prognostic factor; prostate cancer

Prostate cancer $(\mathrm{PCa})$ is one of the most common malignancies and is now the second leading cause of cancer-related death in men in the United States (Parker et al, 1996; Parkin et al, 2002). Several prognostic factors related to the clinicopathologic features have been described. Among them, serum prostate-specific antigen (PSA) level, $\mathrm{T}$ stage and Gleason score are considered very important prognostic factors (Partin et al, 1997; Pound et al, 1997; Kattan et al, 1998; Hull et al, 2002). However, only a few factors that represent the host response which is composed of various inflammatory cells have been reported as prognostic factors for PCa so far (Irani et al, 1999; Wise et al, 2000; Schulz et al, 2007).

Tumour cells are surrounded by inflammatory cells such as macrophages, lymphocytes, neutrophils and mast cells. Inflammatory cell infiltrates, particularly macrophages, may contribute to tumour progression by producing angiogenic factors (Gruber et al, 1995; Jenkins et al, 1995). The role of mast cells in tumour growth has been studied extensively in experimental tumours (Fisher and Fisher, 1965; Tanooka et al, 1982; Burtin et al, 1985), however, the significance of mast cell infiltration around human tumours has not been well studied, even though accumulation of mast cells

*Correspondence: Dr N Nonomura;

E-mail: nono@uro.med.osaka-u.ac.jp

Received 26 March 2007; revised 29 June 2007; accepted 8 August 2007; published online II September 2007 around tumours was first reported a decade ago (Dimitriadou and Koutsilieris, 1997). Most studies have shown that mast cells prevent tumour growth (Farram and Nelson, 1980; Henderson et al, 1981; Ghiara et al, 1985; Benyon et al, 1991). In contrast, in a heterocyclic amine-induced rat PCa model, Nakai et al (2007) reported increased infiltration of stromal mast cell in the ventral prostate, with increased prostatic epithelial proliferation, suggesting that mast cells may have beneficial roles in progression of $\mathrm{PCa}$ (Nakai et al, 2007). The significance of mast cell accumulation around PCa has not been investigated extensively (Gupta, 1970; Sari et al, 1999; Aydin et al, 2002). In the present study, the viability of mast cell accumulation around $\mathrm{PCa}$ as a prognostic factor was examined.

\section{MATERIALS AND METHODS}

\section{Patients}

One hundred and four patients diagnosed with local PCa by transrectal needle biopsy at Osaka University Hospital between 1997 and 2000 were selected for the present study. Written informed consent form approved by our institute was obtained. The ages of the patients ranged from 45 to 88 years (median, 72 years). A diagnosis of PCa was made by histologic examination of 
the biopsy specimens. Clinical stage was defined according to the American staging system (Sobin and Wittekind, 1997) through digital rectal examination (DRE), transrectal ultrasonography, chest X-ray, computed tomography, magnetic resonance imaging and bone scintigram. Serum PSA levels measured by immunoenzymatic assay ranged from 4.3 to $316.8 \mathrm{ng} \mathrm{ml}^{-1}$ (median, $16.9 \mathrm{ng} \mathrm{ml}^{-1}$ ). Clinical stage was distributed as follows: 20 cases $(19.2 \%)$ in stage T1, 46 cases $(44.2 \%)$ in stage $\mathrm{T} 2,36$ cases $(34.6 \%)$ in stage T3 and two cases $(1.9 \%)$ in T4 (Table 1). Biopsy specimens were fixed in $10 \%$ neutral buffered formalin and routinely processed for paraffin embedding. Serial 5 - $\mu$ m-thick sections were cut, stained with haematoxylin and reviewed by one pathologist to determine the Gleason score (Gleason and Mellinger, 1974).

Seventy-five patients underwent radical prostatectomy and remaining 29 received irradiation therapy as initial therapy. No patients received brachytherapy. After initial therapy, patients were followed up with periodic evaluations of DRE, serum PSA and imaging findings. Progression of PCa was defined as an elevated PSA at three consecutive measurements (PSA failure), the appearance of new lesion, reappearance of any lesion that had disappeared or clear worsening of non-measurable disease.

\section{Immunohistochemical analyses}

Mast cells were stained immunohistochemically with a monoclonal antibody against tryptase specific to mast cells (TransGenic Inc., Kobe, Japan). Immunohistochemistry of paraffin sections was carried out with an LSAB kit (Dako, Glostrup, Denmark). For systematic counting, three ocular measuring fields, each with a real area of $0.06175 \mathrm{~mm}^{2}$, were randomly chosen under a microscope at a power of $\times 400$ within a section. If the cancer foci were too small to obtain three independent fields, mast cells were counted in only one or two fields.

\section{Statistical analyses}

Statistical analyses were performed with StatView software (SAS Institute Inc., Cary, NC, USA). Correlation between mast cell count by immunohistochemistry and clinicopathologic parameters was evaluated with the $\chi^{2}$ test (Table 2). The follow-up period for survivors measured from the date of start of therapy, ranged from 2.7 to 181.5 months (mean, 54.5 months). Progression-free survival rate was calculated by the Kaplan-Meier method, and differences in survival curves were estimated with the Log-rank test (Figures 2 and 3). Independent prognostic factors were analysed by Cox proportional hazards regression model in a stepwise manner. $P<0.05$ was considered statistically significant.

Table I Patient characteristics

\begin{tabular}{lc}
\hline & Median (range) \\
\hline Age (years) & $72(45-88)$ \\
Prostate-specific antigen $(\mathrm{ng} / \mathrm{ml})$ & $16.9(4.3-316.8)$ \\
Gleason score & \\
$\leqslant 6$ & $49(44.2 \%)$ \\
7 & $29(27.9 \%)$ \\
$\geqslant 8$ & $26(25.0 \%)$ \\
Clinical T stage & \\
$T \leqslant 2$ & $66(63.4 \%)$ \\
$T \geqslant 3$ & $38(36.5 \%)$ \\
Total & $104(100 \%)$ \\
\hline
\end{tabular}

\section{RESULTS}

\section{Mast cell infiltration of PCa}

Matriptase-positive cells (mast cells) were observed only around the cancer foci (Figure 1). The median number of mast cells infiltrating into the peritumoral area was 16 (range, 5-70). Of the 104 cases, 52 cases had a mast cell count higher than 16 (designated as 'high MC group'), and the remaining 52 patients had a mast cell count lower than 16 (low MC group).

\section{Correlations between mast cell count and various clinicopathologic factors}

The correlations between mast cell count and various clinicopathologic factors are shown in Table 2. Statistical significance was calculated by $\chi^{2}$ test. The mast cell count correlated positively with clinical $\mathrm{T}(P<0.001)$ and with Gleason score $(P<0.05$, Gleason score $\leqslant 6$ vs $7 ; P<0.001$, Gleason score $\leqslant 6$ vs $\geqslant 8 ; P<0.05$, Gleason score $7 v s \geqslant 8$ ). Patients with PSA failure had significantly higher mast cell counts than those with no PSA failure $(P<0.001)$. However, PSA level did not correlate significantly with mast cell count.

Recurrence-free survival analysis of patients treated by radical prostatectomy or irradiation therapy as initial therapies

Progression-free survival rates of 104 patients who underwent radical prostatectomy or irradiation therapy as initial therapies were evaluated. The follow-up period ranged from 2.0 to 96.0 months (mean, 46.8 months). The disease-free survival time ranged from 2.0 to 84.2 months (mean, 32.9 months). Progressionfree survival of the patients with low Gleason score $(<8)$ was significantly better than those with high Gleason score $(\geqslant 8)$, as expected $(P<0.005)$ (Figure $2 \mathrm{~A})$. The median progression-free survival time of the patients with high Gleason scores was 56 months. But, the progression-free survival rate of the patients with low Gleason score did not reach 50\% during the observation period. The significance of mast cell infiltration for progression-

Table 2 Correlation between mast cell infiltration and clinicopathologic factors

\begin{tabular}{|c|c|c|c|}
\hline $\begin{array}{l}\text { Clinicopathologic } \\
\text { factors }\end{array}$ & $\begin{array}{c}\text { Number of patients } \\
(\%)\end{array}$ & $\begin{array}{c}\text { Mast cell } \\
\text { count } \\
\text { Mean (s.e.) }\end{array}$ & $P$-value \\
\hline \multicolumn{4}{|l|}{ Age (years) } \\
\hline$<70$ & 51 (49\%) & $20.35(13.25)$ & NS \\
\hline$\geqslant 70$ & $53(51 \%)$ & $20.11(11.83)$ & \\
\hline \multicolumn{4}{|l|}{$P S A^{b}(n g / m l)$} \\
\hline$<20$ & $54(51.9 \%)$ & | $8.59(10.08)$ & NS \\
\hline$\geqslant 20$ & $50(48.1 \%)$ & $21.74(14.29)$ & \\
\hline \multicolumn{4}{|l|}{ Gleason score (GS) } \\
\hline$G S \leqslant 6$ & 49 (44.2\%) & | 5.80 (8.03) & $<0.05^{\mathrm{c}}$ \\
\hline $\mathrm{GS}=7$ & 29 (27.9\%) & $20.98(13.94)$ & $<0.001^{\circ}$ \\
\hline$G S \geqslant 8$ & $26(25.0 \%)$ & $27.74(14.25)$ & $<0.05^{\mathrm{e}}$ \\
\hline \multicolumn{4}{|l|}{ Clinical T stage } \\
\hline$\leqslant \mathrm{T} 2$ & $66(63.4 \%)$ & | 7.30 (8.26) & $<0.001$ \\
\hline$\geqslant T 3$ & $38(36.5 \%)$ & $25.10(16.39)$ & \\
\hline \multicolumn{4}{|l|}{ PSA failure } \\
\hline+ & $30(28.8 \%)$ & $27.56(15.70)$ & $<0.001$ \\
\hline- & 74 (71.2\%) & | $6.67(8.69)$ & \\
\hline
\end{tabular}

NS, not significant. ${ }^{a}$ Standard error. ${ }^{b}$ Prostate-specific antigen. ${ }^{c} \mathrm{GS} \leqslant 6$ vs GS $=7$. ${ }^{\mathrm{d}} \mathrm{GS} \leqslant 6$ vs $\mathrm{GS} \geqslant 8 .{ }^{e} \mathrm{GS}=7$ vs $\mathrm{GS} \geqslant 8$. 

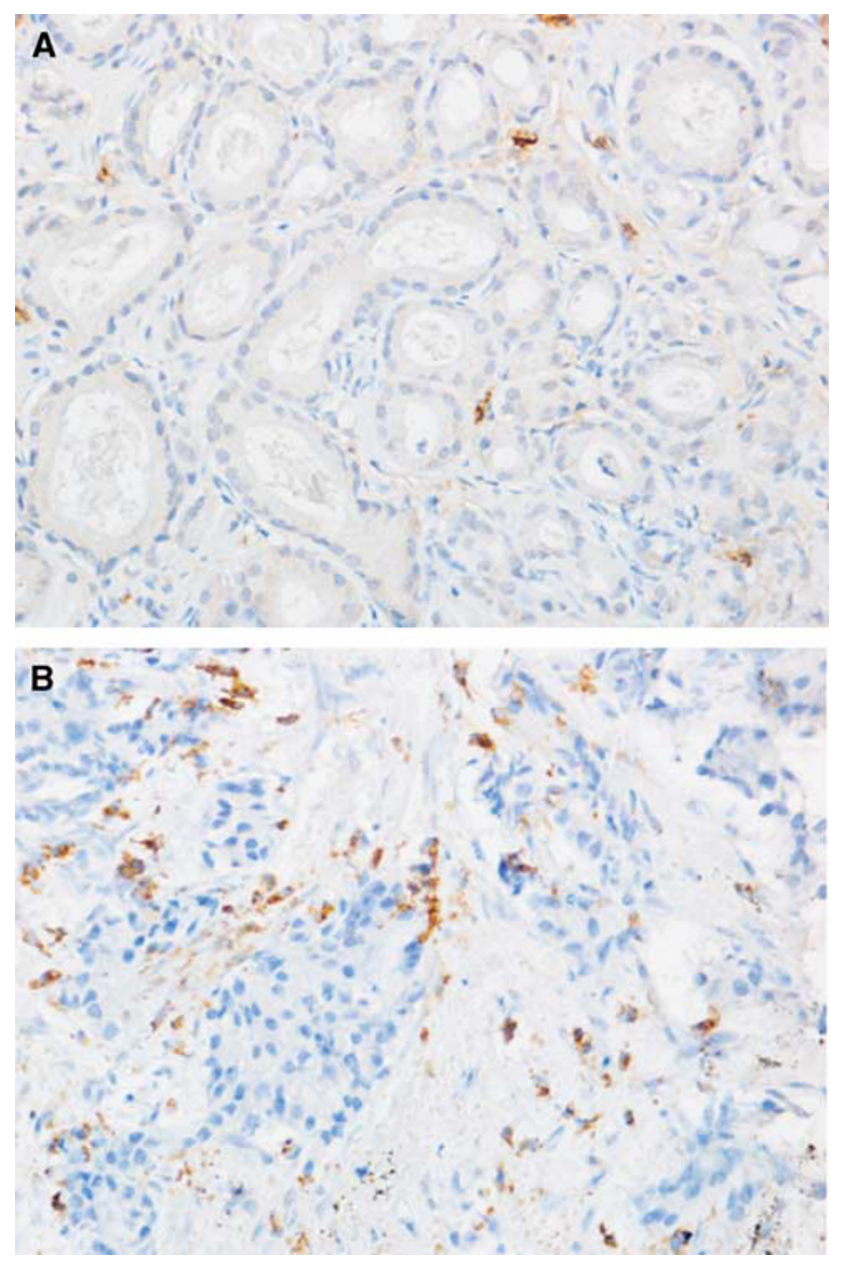

Figure I Immunostaining of mast cells with monoclonal antibody against mast cell-specific tryptase in prostate biopsy specimens. (A) A case with high-level mast cell infiltration. (B) A case with low-level mast cell infiltration. Bar, $20 \mu \mathrm{m}$.

free survival was also analysed. Progression-free survival of the low MC group was significantly better than that of the high MC group $(P<0.0001)$ (Figure $2 \mathrm{~B})$. The median progression-free survival time of the high MC group was 57 months. However, the median progression-free survival time of the low MC group did not reach $50 \%$ during the observation period.

\section{Recurrence-free survival of patients treated with androgen deprivation therapy}

Androgen deprivation therapy is a commonly used therapy for $\mathrm{PCa}$ in Japan. Therefore, we examined progression-free survival of patients who received only androgen deprivation therapy. The progression-free survival in patients with low Gleason score or patients in the low MC group was better than that of patients with high Gleason score or in the high $\mathrm{MC}$ group $(P<0.05)$ (Figure $3 \mathrm{~A}$ and $\mathrm{B})$. The median progression-free survival time of the patients with high and low Gleason scores were 30 and 68 months, respectively. The median progression-free survival of the high MC group was 57 months, but the progression-free survival rate of the low MC group did not reach $50 \%$ during the observation period.

\section{Cox multivariate analysis for prognostic factors}

Results of Cox multivariate analysis are shown in Table 3. Mast cell infiltration (mast cell count $>16$ ), Gleason score $(>7)$ and
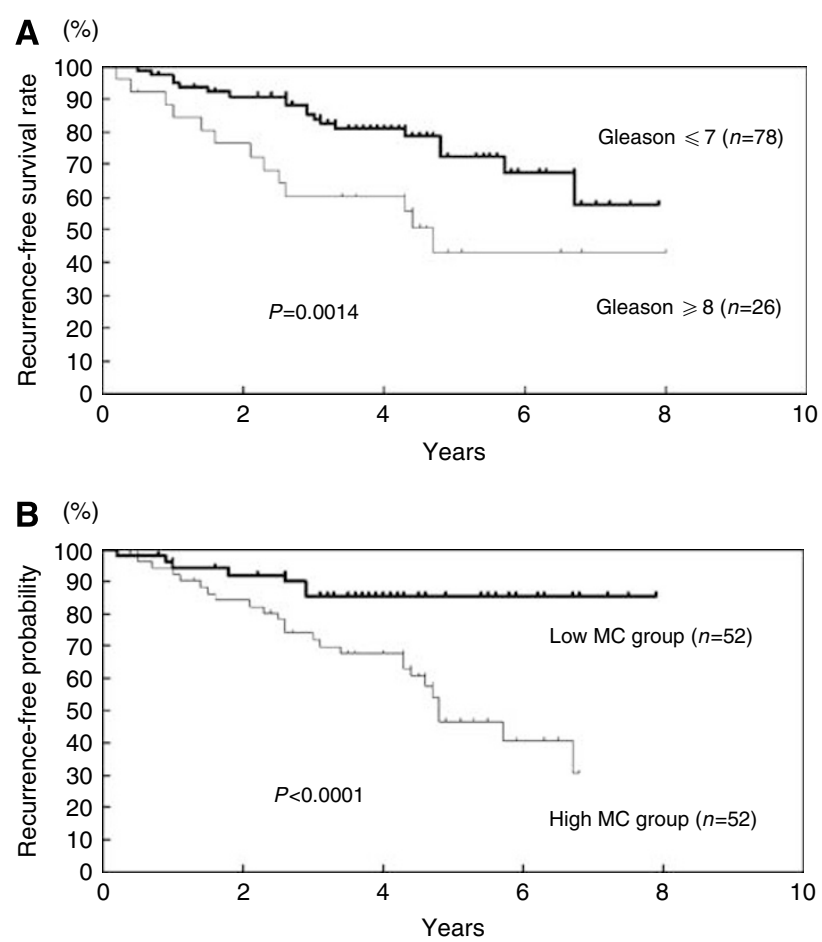

Figure 2 Progression-free survival of PCa patients stratified by Gleason score (GS) or mast cell infiltration. (A) Progression-free survival of PCa patients with high and low Gleason scores. (B) Progression-free survival of $\mathrm{PCa}$ patients in high and low mast cell (MC) counts. High Gleason score, $\mathrm{GS} \geqslant 8$; low Gleason score, GS $\leqslant 7$. High MC group, > 16; low MC group, $\leqslant 16$

extraprostatic extension (positive) were significant factors for progression-free survival. However, mast cell infiltration had the lowest $P$-value and the highest hazard ratio (2.726).

\section{DISCUSSION}

It has been long recognized that inflammatory cell infiltration is often seen around many types of tumours (Dimitriadou and Koutsilieris, 1997). Most attention focused on the role of infiltration lymphoid cells such as tumour-infiltrating lymphocytes, which represent the host immune reaction against the tumour (Romero et al, 1998; Molldrem et al, 2000; Zhang et al, 2003). There have been a number of reports regarding mast cell infiltration around a variety of human and experimentally induced tumours (Ueda et al, 1988; Dimitriadou and Koutsilieris, 1997; Takanami et al, 2000; Ribatti et al, 2004; Tuna et al, 2006).

In general, peripheral distribution of mast cells around an experimentally induced tumour has been recognized as playing a protective role against the tumours (Farram and Nelson, 1980; Tanooka et al, 1982; Burtin et al, 1985). In these tumours, mast cells and their degranulation products (histamine, serotonin and heparin) have been reported to be involved in tumour inhibition (Tharp et al, 1989; Benyon et al, 1991). It has been reported that the incidence of metastases as well as the appearance of tumours correlates inversely with tissue histamine level and mast cell count (Burtin et al, 1985). Interestingly, isolated mast cells were shown to inactivate tumour cells selectively in vitro (Henderson et al, 1981). These findings suggest that mast cells may play a role in inhibiting tumour metastases and suppressing growth of primary tumours. The protective roles of mast cell infiltration have been reported in soft tissue sarcomas in both human and animal models (Ueda et al, 1988). 

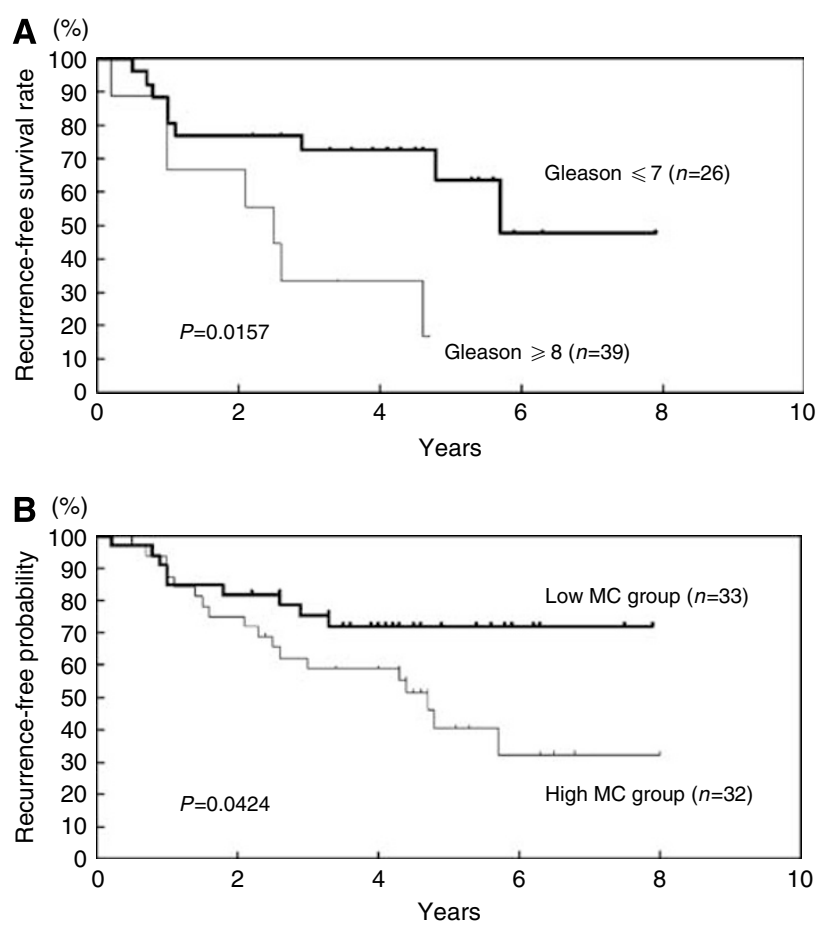

Figure 3 Progression-free survival of $\mathrm{PCa}$ patients treated with androgen deprivation therapy stratified by Gleason score or mast cell infiltration. (A) Progression-free survival of PCa patients with high and low Gleason scores. (B) Progression-free survival of PCa patients with high and low mast cell $(M C)$ counts. High Gleason score, GS $\geqslant 8$; low Gleason score, GS $\leqslant 7$. High MC group, > 16, low MC group, $\leqslant 16$.

In contrast to the findings in experimentally induced malignancies, some studies have suggested promote that mast cells tumour progression. For instance, mast cell infiltration correlates well with tumour angiogenesis and metastases in gastric cancer (Yano et al, 1999), colorectal cancer (Lachter et al, 1995), pulmonary adenocarcinoma (Takanami et al, 2000) and renal cell carcinoma (Tuna et al, 2006). In PCas, mast cell infiltration correlates with poor prognosis, suggesting that mast cells may promote tumour progression. Interestingly, in our series of studies, a low mast cell count was associated with longer recurrence-free survival of the patients receiving hormonal therapies. In some immunohistochemical studies, significant associations between mast cell number and microvessel density were reported (Takanami et al, 2000; Tuna et al, 2006). Mast cells are known to produce several mediators of
Table 3 Prognostic factors by Cox regression analysis

\begin{tabular}{lccc}
\hline $\begin{array}{l}\text { Clinicopathologic } \\
\text { factors }\end{array}$ & $\begin{array}{c}\text { Hazard } \\
\text { ratio }\end{array}$ & $\begin{array}{c}\mathbf{9 5 \%} \text { confidence } \\
\text { interval }\end{array}$ & P-value \\
\hline $\begin{array}{l}\text { Age (continuous } \\
\text { variable) }\end{array}$ & 0.979 & $0.609-1.575$ & 0.9312 \\
$\begin{array}{l}\text { PSA level at biopsy } \\
\text { (continuous variable) }\end{array}$ & 0.999 & $0.997-1.000$ & 0.526 \\
$\begin{array}{l}\text { Gleason score }>7 \\
\text { DRE positive }\end{array}$ & 1.635 & $1.000-2.67 \mid$ & 0.0498 \\
$\begin{array}{l}\text { Extraprostatic } \\
\text { extension (+) }\end{array}$ & 0.814 & $0.385-1.721$ & 0.5907 \\
$\begin{array}{l}\text { Lymph node } \\
\text { metastasis }(+)\end{array}$ & 2.616 & $1.389-4.925$ & 0.0029 \\
Mast cell count $>16$ & 0.978 & $0.200-4.778$ & 0.9778 \\
\hline
\end{tabular}

DRE $=$ digital rectal examination; PSA = prostate-specific antigen.

angiogenesis, including fibroblast growth factor (FGF)-2, vascular endothelial cell growth factor (VEGF), transforming growth factor (TGF)- $\beta$ and interleukin (IL)-8 (reviewed by Ribatti et al, 2004). These factors are all involved both in normal as well as tumour-associated angiogenesis. In addition to these angiogenic factors, mast cells also produce proteolytic enzymes such as matrix metalloproteinase (MMP)-2 and -9 , and tryptase (Fang et al, 1999; Vincent et al, 2000; Di Girolamo et al, 2006). These factors are known to promote invasion of cancer cells into interstitial stromal tissue. Moreover, tryptase is one of the proteolytic enzymes produced specifically by mast cells. In the present study, we stained mast cells in prostate biopsy specimens with antibody against mast cell-specific tryptase. Mast cell-specific tryptase may also promote cancer cell invasion (Stack and Johnson, 1994; Blair et al, 1997). Because microvessels are usually very sparse in prostate biopsy specimens, the correlation between microvessels and mast cell infiltration was not examined in the present study.

Gupta (1970) first reported the presence of mast cells around PCas. In our study, we observed mast cell aggregation at the periphery of PCas, similar to previous reports (Sari et al, 1999; Aydin et al, 2002). However, this is the first report that mast cell infiltration around prostate tumours is a significant prognostic factor for PCa.

\section{ACKNOWLEDGEMENTS}

This work was supported in part by a Grant-in-Aid for Scientific Research from the Ministry of Education, Culture, Sports, Science and Technology of Japan.

\section{REFERENCES}

Aydin OA, Dusmez D, Cinel L, Doruk E, Kanik A (2002) Immunohistological analysis of mast cell numbers in the intratumoral and peritumoral regions of regions of prostate carcinoma compared to benign prostatic hyperplasia. Pathol Res Pract 198: 267-271

Benyon RC, Bissonnette EY, Befus AD (1991) Tumor necrosis factor alphadependent cytotoxicity of human skin mast cells is enhanced by anti-IgE antibodies. J Immunol 147: 2253-2258

Blair RJ, Meng H, Marchese MJ, Ren S, Schwartz LB, Tonnesen MG, Gruber BL (1997) Human mast cells stimulate vascular tube formation. Tryptase is a novel, potent angiogenic factor. J Clin Invest 99: $2691-2700$

Burtin C, Ponvert C, Fray A (1985) Inverse correlation between tumor incidence and tissue histamine levels in $\mathrm{W} / \mathrm{W}^{\mathrm{v}}, \mathrm{W} /+$, and $+/+$ mice. J Natl Cancer Inst 74: 671-674
Di Girolamo N, Indoh I, Jackson N, Wakefield D, McNeil HP, Yan W, Geczy C, Arm JP, Tedla N (2006) Human mast cell-derived gelatinase B (matrix metalloproteinase-9) is regulated by inflammatory cytokines: role in cell migration. J Immunol 177: 2638-2650

Dimitriadou V, Koutsilieris M (1997) Mast cell-tumor cell interactions: for or against tumor growth and metastasis? Anticancer Res 17: $1541-1550$

Fang CK, Wolters PJ, Steinhoff M, Bidgol A, Blount JL, Caughey GH (1999) Mast cell expression of gelatinases $A$ and $B$ is regulated by kit ligand and TGF- $\beta$. J Immunol 162: $5528-5535$

Farram E, Nelson DS (1980) Mouse mast cell as antitumor effector cells. Cell Immunol 52: 294-301

Fisher ER, Fisher B (1965) Roles of mast cells in tumor growth. Arch Pathol 79: $185-191$ 
Ghiara P, Boraschi D, Villar L, Scapigliati G, Taddei C, Taliabue A (1985) In vitro generated mast cells express natural cytotoxicity against tumor cells. Immunology 55: 317-324

Gleason DF, Mellinger GT (1974) Prediction of prognosis for prostatic adenocarcinoma by combined histological grading and clinical staging. J Urol 111: 58-64

Gruber BL, Marchase MJ, Kaw R (1995) Angiogenic factors stimulate mast cell migration. Blood 86: 2488-2493

Gupta RK (1970) Mast cell variations in prostate and urinary bladder. Arch Pathol 89: $302-305$

Henderson WR, Chi EY, Jong EC, Klebanoff SJ (1981) Mast cell-mediated tumor cell cytotoxicity. Role of peroxidase. J Exp Med 153: 520-524

Hull GW, Rabbani F, Abbas F, Wheeler TM, Kattan MW, Scardino PT (2002) Cancer control with radical prostatectomy alone in 1000 consecutive patients. J Urol 167: 528-534

Irani J, Goujon JM, Ragni E, Peyrat L, Hubert J, Saint F, Mottet N (1999) High-grade inflammation in prostate cancer as a prognostic factor for biochemical recurrence after radical prostatectomy. Pathologist Multi Center Study Group. Urology 54: 467-472

Jenkins DC, Charles IG, Thompson LL, Moss DW, Holmes LS, Baylis SA, Rhodes P, Westmore K, Emson PC, Moncada S (1995) Roles of nitric oxide in tumor growth. Proc Natl Acad Sci USA 92: 4392-4396

Kattan MW, Eastham JA, Stapleton AM, Wheeler TM, Scardino PT (1998) A preoperative nomogram for disease recurrence following radical prostatectomy for prostate cancer. J Natl Cancer Inst 90: 766-771

Lachter J, Stein M, Lichtig C, Eidelman S, Munichor M (1995) Mast cells in colorectal neoplasias and premalignant disorders. Dis Colon Rectum 38: $290-293$

Molldrem JJ, Lee PP, Wang C, Felio K, Kantarjian HM, Champlin RE, Davis MM (2000) Evidence that $\mathrm{T}$ lymphocytes may participate in the elimination of chronic myelogenous leukemia. Nat Med 6: 1018-1023

Nakai Y, Nelson WG, DeMarzo AM (2007) The dietary charred meat carcinogen 2-amino-1-methyl-6-phenylimidazo[4,5-b]pyridine acts as both a tumor initiator and promoter in the rat ventral prostate. Cancer Res 67: $1378-1384$

Parker SL, Tong T, Bolden S, Wingo PA (1996) Cancer statistics, 1996. CA Cancer J Clin 46: 5-27

Parkin DM, Whelan SL, Ferlay J, Teppo L, Thomas DB (2002) Cancer Incidence in Five Continents, vol. VIII. Lyon: IARC Scientific Publ.

Partin AW, Kattan MW, Subong EN, Walsh PC, Wonjo KJ, Oesterling JE, Scardino PT, Pearson JD (1997) Combination of prostate-specific antigen, clinical stage, and Gleason score to predict pathological stage of localized prostate cancer. A multi-institutional update. JAMA 277: 1445 - 1451

Pound CR, Partin AW, Epstein JI, Walsh PC (1997) Prostate-specific antigen after anatomic radical retropubic prostatectomy. Urol Clin North Am 24: 395 - 406

Ribatti D, Crivellato E, Roccaro AM, Ria R, Vacca A (2004) Mast cell contribution to angiogenesis related to tumour progression. Clin Exp Allergy 34: $1660-1664$
Romero P, Dunbar PR, Valmori D, Pittet M, Ogg GS, Remoldi D, Chen JL, Lienard D, Cerottini JC, Cerundolo V (1998) Ex vivo staining of metastatic lymph nodes by class I major histocompatibility complex tetramers reveals high numbers of antigen-experienced tumorspecific cytotoxic T lymphocytes. J Exp Med 188: $1641-1650$

Sari A, Serel TA, Candir O, Ozturk A, Kosar A (1999) Mast cell variations in tumour tissue and with histopathological grading in specimens of prostatic adenocarcinoma. BJU Int 84: $851-853$

Schulz WA, Alexa A, Jung V, Hader C, Hoffmann MJ, Yamanaka M, Frizsche S, Wlazlinski A, Muller M, Lengauer T, Engers R, Florl AR, Wullich B, Rahnenfhrer J (2007) Factor interaction analysis for chromosome 8 and DNA methylation alterations highlights innate immune response suppression and cytoskeletal changes in prostate cancer. Mol Cancer 6: 14, doi: 10.1186/1476-4598-6-14

Sobin LH, Wittekind Ch (1997) TNM classification of malignant tumors, 5 th edn. New York: Wiley-Liss Inc

Stack MS, Johnson DA (1994) Human mast cell tryptase activates singlechain urinary-type plasminogen activator (pro-urokinase). J Biol Chem 269: $9416-9419$

Takanami I, Takeuchi K, Naruke M (2000) Mast cell density is associated with angiogenesis and poor prognosis in pulmonary adenocarcinoma. Cancer 88: $2682-2692$

Tanooka H, Kitamura Y, Sado T, Tanaka K, Nagase M, Kondo S (1982) Evidence for involvement of mast cells in tumor suppression in mice. J Natl Cancer Inst 69: 1305-1309

Tharp MD, Kasper C, Thiele D, Charley MR, Kennerly DA, Sullivan TJ (1989) Studies of connective tissue mast cell-mediated cytotoxicity. Invest Dermatol 93: $423-428$

Tuna B, Yorukoglu K, Unlu M, Mungan MU, Kirkali Z (2006) Association of mast cells with microvessel density in renal cell carcinomas. Eur Urol 50: $530-534$

Ueda T, Aozasa K, Tsujimoto M, Yoshikawa H, Kato T, Ono K, Matsumoto $\mathrm{K}$ (1988) Prognostic significance of mast cells in soft tissue sarcoma. Cancer 62: $2416-2419$

Vincent AJ, Zhang J, Ostor A, Rogers PA, Affandi B, Kovacs G, Salamonsen LA (2000) Matrix metalloproteinase- 1 and -3 and mast cells are present in the endometrium of women using progestin-only contraceptives. Hum Reprod 15: $123-130$

Wise GJ, Marella VK, Talluni G, Shirazian D (2000) Cytokine variations in patients with hormone treated prostate cancer. J Urol 164: $722-725$

Yano H, Kinuta M, Tateishi H, Nakano Y, Matsui S, Monden T, Okamura J, Sakai M, Okamoto S (1999) Mast cell infiltration around gastric cancer cells correlates with tumor angiogenesis and metastasis. Gastric Cancer 2: $26-32$

Zhang L, Conejo Jr G, Katsaros D, Gimotty PA, Massobrio M, Regnani G, Makrigiannakis A, Gray H, Schienger K, Liebman MN, Rubin SC, Coukos $\mathrm{G}$ (2003) Intratumoral $\mathrm{T}$ cells, recurrence, and survival in epithelial ovarian cancer. $N$ Engl J Med 348: $203-213$ 